\title{
Groundwater Withdrawal-Induced Land Subsidence
}

\author{
Contributor: , Artur Guzy ${ }^{1}$
}

1, The Department of Mining Surveying and Environmental Engineering, AGH University of Science and Technology, 30-059 Kraków, Poland; aguzy@agh.edu.pl

Version received: 27 August 2020

check for updates

\section{Definition}

This entry presents a comprehensive review of models used to predict land surface displacements caused by rock mass drainage, as well as (2) recent advances and (3) a summary of InSAR implementation over recent years to support the aquifer compaction modelling process. Therefore, the study presented would be of benefit to readers who are interested in the topic of interaction between the human population and the hydrogeological system in different regions. The research presented allows readers to better understand the factors, developments and effects of groundwater drainage and thus facilitate large - scale risk assessment and preventive planning.

\section{Definition}

Land subsidence is probably one of the most evident environmental effects of groundwater pumping. Globally, freshwater demand is the leading cause of this phenomenon. Land subsidence induced by aquifer system drainage can reach total values of up to $14.5 \mathrm{~m}$. The spatial extension of this phenomenon is usually extensive and is often difficult to define clearly. Aquifer compaction contributes to many socio-economic effects and high infrastructure-related damage costs. Currently, many methods are used to analyze aquifer compaction. These include the fundamental relationship between groundwater head and groundwater flow direction, water pressure and aquifer matrix compressibility. Such solutions enable satisfactory modelling results. However, further research is needed to allow more efficient modelling of aquifer compaction. Recently, satellite radar interferometry (InSAR) has contributed to significant progress in monitoring and determining the spatio-temporal land subsidence distributions worldwide. Therefore, implementation of this approach can pave the way to the development of more efficient aquifer compaction models.

\section{Introduction}

Land subsidence is one of the most important environmental effects of groundwater pumping $[\underline{1}][\underline{2}][\underline{3}][\underline{4}][\underline{5}][\underline{6}][\underline{7}]$. The proper assessment of the origin, mechanism and impact of this process is a common problem. Globally, the growing demand for fresh water is one of the leading causes of this phenomenon []․ This is the result of the rapid population growth observed since the 1950 s ${ }^{[0]}$ ] $[\underline{9}]$. Fresh water for industrial purposes is usually supplied by direct pumping of water from aquifer systems, which have not been contaminated by external factors. This results in the compaction of compressible aquifers [10][11]. Drainage-induced land subsidence values may reach up to $14.5 \mathrm{~m}[\underline{11]}$. Compacting aquifers contribute to many social and economic disadvantages [를. The most severe of these include damage to the surface and underground infrastructure and increased risk of flooding in coastal cities [ $\underline{13}][\underline{14}][\underline{15}]$.

One of the first documented land subsidence certificates linked to "unspecified geomechanical underground processes" dates back to 1926. It is attributed to W.E. Pratt and D.W. Johnson [16], U.S. geologists conducting ground surface transformation studies induced by oil production in the Goose Creek field in Baytown, Texas. Since then, significant progress has been made in the recognition of the physics of the phenomenon under investigation [릴. Basic hydrogeological and geomechanical concepts have been developed for the aquifer compaction process. In addition, the measurement capacity of land 
surface displacement has been improved. It is, therefore, possible to determine aquifer compaction more precisely. These activities were crucial in defining models for exploring past and predicting future land surface drainage-induced displacements. Finally, based on the findings of models implemented in this way, initiatives have also been applied to reduce and reverse the environmental and anthropogenic

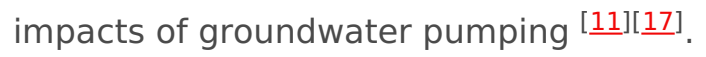

Many approaches have been used for the analysis and simulation of aquifer compaction. These include the fundamental relationship between the groundwater head and groundwater flow direction and water pressure and aquifer compaction. Progress in compaction modelling has mainly been related to the development of computer technologies and intensive work on numerical algorithms. These have been carried out since the 1970s. The results of these works have made it possible to solve complex mathematical dependencies that describe the process of rock mass compaction with respect to drainage [11]. Given this, the numerical solutions developed so far that have been used on a large scale have made it possible to obtain satisfactory modelling results. However, due to the significant parameterization of the theoretical models commonly used today, the work is often time-consuming and complicated. It is, therefore, noted that further research is needed to allow more efficient modelling of the drainage-induced displacement of the land surface [18].

The implementation of Interferometric Synthetic Aperture Radar (InSAR) seems to be one of the most promising approaches in this regard. The rapid development of this ground monitoring technology over the last 10 years has contributed to significant progress in the monitoring of drainage-related land surface movements in many countries across the world [11][19]. The use of computational groundwater flow simulation models, combined with InSAR results, enables a much broader approach to the assessment of water hazards [리 $[\underline{21}][\underline{22}]$. Currently, both techniques are widely used to help understand the phenomenon of aquifer compaction linked to groundwater withdrawal. The implementation of InSAR in the process of creating prediction models makes it possible to determine more effectively structural boundaries of aquifer systems, the spatio-temporal distribution of ground surface displacements, and the hydrogeological heterogeneity of the aquifer system, as well as the values of storage coefficients and hydraulic conductivity. These studies are based on the use of advanced satellite differential radar interferometry (A-DInSAR) techniques. A-DInSAR techniques assume the processing of multiple interferograms generated from large datasets of radar images [23][려]. Such techniques can be applied in order to collect time-series of land surface movements over wide areas with millimetre accuracy $[\underline{25}][\underline{26}][\underline{27}]$. For example, the use of wide-area InSAR survey processed with the Small Baseline Subset (SBAS) and Persistent Scatter (PS) InSAR method made it possible to analyse deformation at geothermal exploitation sites and its relationship with energy production in the area of the eastern Trans-Mexican Volcanic Belt $\left.{ }^{[28}\right]$, and to detect ground millimetric movements in Ravenna and Ferrara, Italy [29]. The substantial improvement in A-DInSAR techniques witnessed over the last few years is primarily linked to the development of advanced computational algorithms [ ${ }^{30}$ ]. However, it is also the result of increased possibilities for the acquisition of radar images by new satellite missions. The Sentinel mission and the Open Source Data Sharing Policy of the European Space Agency are particularly noteworthy [31].

\section{Groundwater Withdrawal-Induced Land Subsidence as a Global Problem}

Land subsidence is one of the most common geomechanical and geotechnical consequences of pumping groundwater. The use of groundwater resources for private and industrial purposes has, in many cases, led to significant depletion, continuous deformations of the land surface and, consequently, to social and

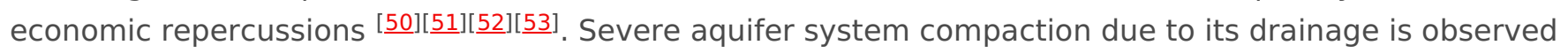
in many urban areas worldwide (Figure 1). The problem is, however, especially critical in the large coastal cities of South-East Asia. Coastal cities are usually located on the loose, unconsolidated alluvial deposits. The degree of compaction of such deposits is considerable. Given the steadily increasing average level of the world's oceans, the coastal areas, which are affected by natural compaction due to, e.g., the consolidation process of river deltas and additional exposure to the phenomenon of drainage- 
induced aquifer compaction, are particularly prone to increased risk of flooding ( ${ }^{[32]}$ ). The problem of rapid and severe aquifer compaction is also present in large centres such as Los Angeles [풀, Mexico $\left.{ }^{\left[{ }^{[34}\right]}\right)$, New Orleans $\left[{ }^{[35]}\right.$, Ho Chi Minh $\left[\underline{36]}\right.$, Teheran ${ }^{[37]}$, Bangkok ${ }^{[\underline{38}]}$ and Beijing $\left.{ }^{[39}\right]$. Increased demand for fresh groundwater resources due to an increase in population and arable land density is also a particular challenge in desert and semi-desert areas ${ }^{[40]}$. Excessive water exploitation has led not only to a significant lowering of the groundwater head and the occurrence of drainage-induced land subsidence, but also to the inflow of saltwater into the land and thus salinization of large areas of land [41]][42]. In all the cases described, the compaction of the aquifer system causes serious damage to the surface and underground infrastructure. It is estimated that the total cost of repairs for this type of damage exceeds tens of billions of Euro and, in many cases, it is impossible to make accurate estimates []][32].

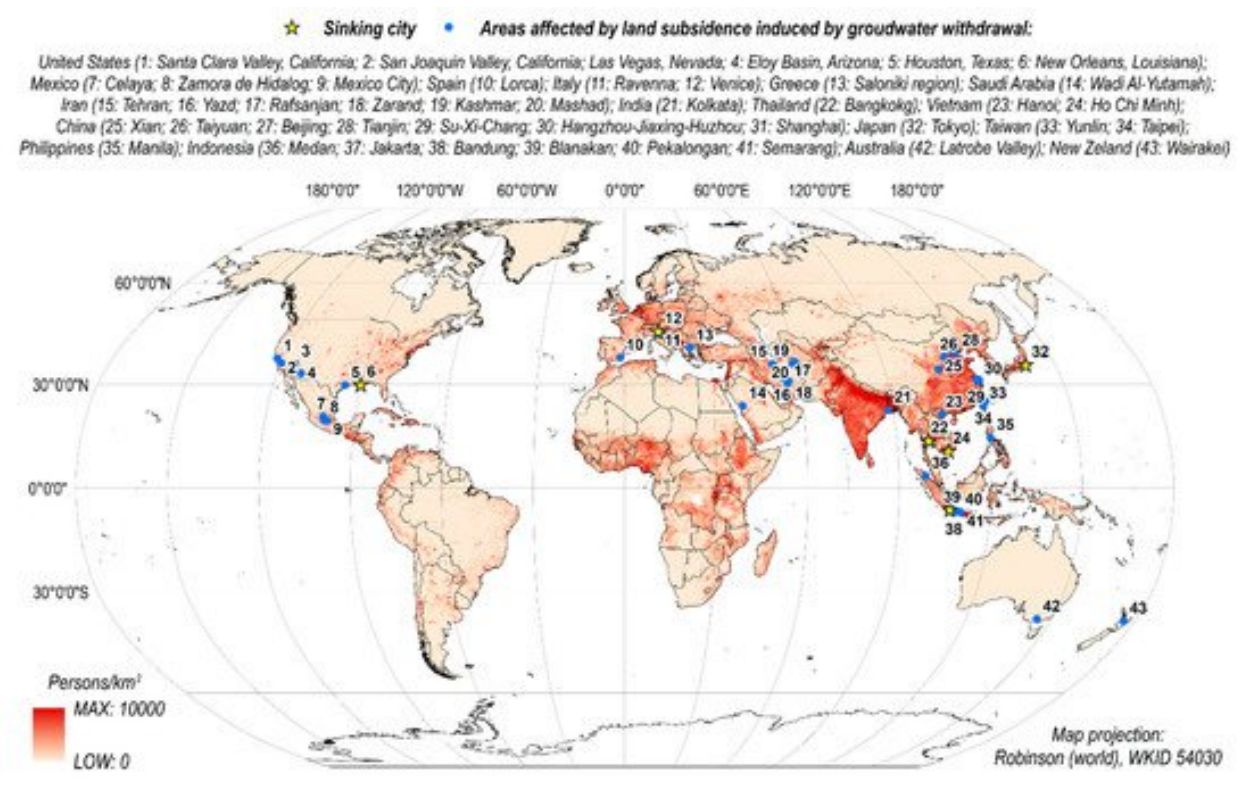

Figure 1. Main areas of the world where anthropogenic land subsidence has been induced by overexploitation of groundwater (blue dots; source of data $[\underline{11][43]})$. Yellow stars indicate coastal areas that are prone to the increased risk of flooding. Note, these are mainly located in densely populated areas of

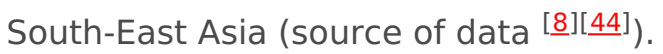

Ground surface movements resulting from rock mass drainage can range from a few centimetres to several meters $\left.{ }^{[11}\right]$. The spatial extension of this phenomenon is usually extensive (even on a regional scale) and, in many cases, difficult to determine precisely. The maximum recorded value of this subsidence is $14.5 \mathrm{~m}$. It is caused by the pumping of water in the geothermal field of Wairakei in New Zealand [6][드]. However, land subsidence of up to $10 \mathrm{~m}$ is also observed in several other parts of the world, including San Joaquin Valley, California [42] and Mexico City, Mexico [34][466]. The spatial range of the phenomenon can be extensive and can reach up to approximately $13,500 \mathrm{~km} 2$ in the San Joaquin Valley ${ }^{[42]}$. China is currently the country with the largest cumulative area (approximately $80,000 \mathrm{~km} 2$ )

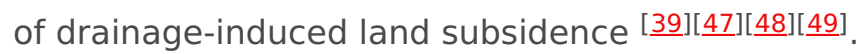

The issues related to ground surface movements induced by rock mass drainage are becoming increasingly important in terms of global climate change. Between 1960 and 2010, the estimated global consumption of groundwater increased by more than twice, and in 2010 it was approx. $2000 \mathrm{~km} 3 /$ year [53]. At present, extensive usage of water resources, including groundwater, is reported primarily in India, Pakistan, China, U.S., Mexico, Southern Europe, Northern Iran and the Nile Delta. Over $90 \%$ of the world's agricultural areas are in these places ${ }^{[53}$. By the end of 2099, further water consumption is expected in many parts of the world. This growth will be particularly strong in central Africa, South-East Asia, the western U.S., Mexico and central South America. Water consumption is increasing primarily due to rapid population growth and industrial activity in developing countries as well as climate changes, e.g., more frequent and longer drought periods. Given the above, the risk of intensification associated with the drainage-induced land subsidence is expected to increase over this century [53]. 


\section{Geomechanics of Aquifer Response to Groundwater Withdrawal}

As a diffuse medium, the groundwater system responds to changes in external and internal boundary fluxes (recharge and discharge) by changing its storage properties and hydraulic pressure. However, these changes have an impact on the flow of water within the aquifer. The depletion of groundwater is one of the factors most used to determine the sustainability of groundwater resources. Over-exploited aquifers are usually depleted. As a result, there is a long-term decrease in groundwater storage and hydraulic pressure in aquifers ${ }^{[54]}$. Depending on whether the environmental, economic and social consequences of groundwater depletion are acceptable or not, the use of groundwater may be considered sustainable or unbalanced $[\underline{55}][\underline{56}]$.

The mechanism by which the aquifer deforms as a consequence of a change in the groundwater head is well recognized. The disturbance of the natural groundwater flow system, e.g., by introducing of a well that pumps water out of this system, disrupts the hydrostatic balance of the aquifer system. It spreads in the space of this mass as a function of time, forming a cone of depression. Within a depression cone, a decrease in hydrostatic pressure is observed (Figure 2).

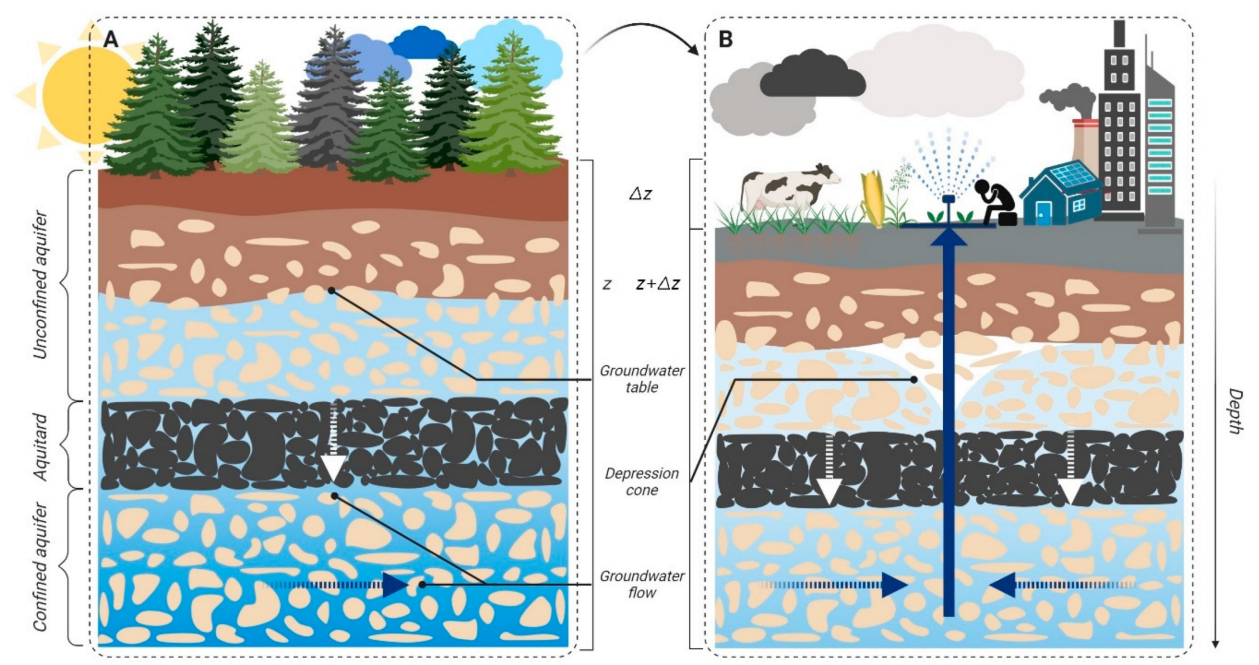

Figure 2. Schematic vertical cross-section of the groundwater system containing relatively coarse(aquifers) and fine-grained (aquitard) deposits; (A) original hydrodynamic equilibrium; (B) disruption of the initial hydrodynamic balance as a consequence of groundwater pumping; lowering of the groundwater table and compaction of the compressible aquifer resulting in land subsidence.

\section{Simulation of Land Subsidence Due to Groundwater Withdrawal}

Various methods of modelling the land displacements induced by rock mass drainage can be distinguished in the literature. In 1984, Poland made one of the first attempts to classify these methods [57]. He classified the methods into three basic categories: theoretical methods (1); semi-theoretical methods (2); and empirical methods (3). Since then, this classification has also been referenced by other researchers and presented in different review articles. Methods (1), (2) and (3) are relatively well presented in other articles and have been used by many researchers. In this article, therefore, we focus only on describing the most important assumptions of these methods and on updating the case studies in which these methods were used. However, given the many disadvantages associated with the use of methods (1), (2) and (3), as well as the rapid development of computational algorithms based on artificial intelligence (Al), several new attempts to model land surface displacement have been identified in the literature in recent years. A distinction can be made between methods based on the function of influence and Al. Therefore, we decided that Poland's classification would be updated and extended with two categories: methods using influence functions (4); and methods based on $\mathrm{Al}$ (5). 


\section{InSAR as a Supportive Tool for Groundwater Withdrawal- Related Subsidence Prediction Models}

To manage groundwater and to prevent or reduce land subsidence, it is essential to have an aquifer deformation model that makes it possible to predict the land subsidence that will occur due to changes in the groundwater system. The starting point for the development of a deformation model, at any location, is the availability of land surface displacement rates that could be nowadays achieved primarily with the use of InSAR. The most significant parameters used in modelling approaches can be derived from InSAR data to improve groundwater models. This can be done by the proper processing and interpretation of such information. The solution, therefore, allows the groundwater manager to consider different scenarios that result in changes in the groundwater head, and then to use the predicted changes to determine the corresponding subsidence rates.

InSAR is increasingly used in hydrogeology due to its high accuracy in measuring ground surface displacement, wide-area coverage and cost-effectiveness. The use of InSAR in hydrogeological research allows for a much broader approach to water hazard assessment. The rapid development of this measurement technology over the last dozen years has improved the possibilities of mapping, monitoring and simulation of groundwater flow in the compacted aquifer system ${ }^{[11]}$. Quantitative observations of land surface displacements and estimates of hydrogeological parameters obtained from InSAR data are very useful in constructing regional hydrogeological models of groundwater flow and

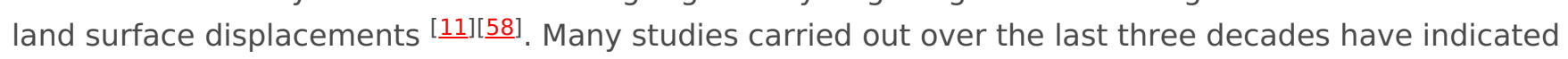
that surface displacement associated with the deformation of the aquifer system are not only common

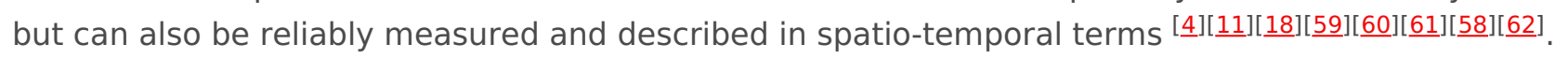

Due to the considerable amount of research conducted on the use of InSAR in hydrogeological studies, only the most crucial examples are presented ${ }^{[58]}$. These aim at determining the following:

- structural boundaries of aquifer systems (e.g., tectonic faults);

- the spatio-temporal distribution of land surface displacements and hydrogeological heterogeneity of aquifer system;

values of storage coefficients and hydraulic conductivity of the aquifer system.

\section{Conclusion}

As groundwater demand increases globally, more reservoirs are experiencing land surface displacement, making it essential that to be able to accurately model the impacts of groundwater depletion and develop effective management strategies for the reduction or prevention of land subsidence. InSAR data is being acquired on a global scale, and the acquisition of such data is increasing to map groundwater systems. The integration of modelling approaches with InSAR data sets therefore provides a new way of obtaining accurate models of aquifer compaction driven by changes in groundwater systems.

\section{References}

1. Gambolati, G.; Ricceri, G.; Bertoni, W.; Brighenti, G.; Vuillermin, E. Mathematical Simulation of the Subsidence of Ravenna. Water Resour. Res. 1991, 27, 2899-2918, doi:10.1029/91wr01567.

2. Ortega-Guerrero, A.; Rudolph, D.L.; Cherry, J.A. Analysis of Long-Term Land Subsidence near Mexico City: Field Investigations and Predictive Modeling. Water Resour. Res. 1999, 35, 3327-3341, doi:10.1029/1999wr900148.

3. Ehlen, J.; Haneberg, W.C.; Larson, R.A.; Holzer, T.L.; Galloway, D.L. Impacts of Land Subsidence Caused by Withdrawal of Underground Fluids in the United States. In Humans as Geologic Agents; Geological Society of America: Boulder, CO, USA, 2007; Volume 16, pp. 87-99, doi:10.1130/2005.4016(08).

4. Teatini, P.; Ferronato, M.; Gambolati, G.; Gonella, M. Groundwater Pumping and Land Subsidence in the EmiliaRomagna Coastland, Italy: Modeling the Past Occurrence and the Future Trend. Water Resour. Res. 2006, 42, doi:10.1029/2005WR004242.

5. Shi, X.Q.; Xue, Y.Q.; Ye, S.J.; Wu, J.C.; Zhang, Y.; Yu, J. Characterization of Land Subsidence Induced by Groundwater 
Withdrawals in Su-Xi-Chang Area, China. Environ. Geol. 2007, 52, 27-40, doi:10.1007/s00254-006-0446-3.

6. Allis, R.; Bromley, C.; Currie, S. Update on Subsidence at the Wairakei-Tauhara Geothermal System, New Zealand. Geothermics 2009, 38, 169-180, doi:10.1016/j.geothermics.2008.12.006.

7. Mahmoudpour, M.; Khamehchiyan, M.; Nikudel, M.R.; Ghassemi, M.R. Characterization of Regional Land Subsidence Induced by Groundwater Withdrawals in Tehran, Iran; Geopersia 2013, 3, 49-62, doi:10.22059/JGEOPE.2013.36014.

8. Erkens, G.; Bucx, T.; Dam, R.; De Lange, G.; Lambert, J. Sinking Coastal Cities. Proc. Int. Assoc. Hydrol. Sci. 2015, doi:10.5194/piahs-372-189-2015.

9. Famiglietti, J.S.; Lo, M.; Ho, S.L.; Bethune, J.; Anderson, K.J.; Syed, T.H.; Swenson, S.C.; De Linage, C.R.; Rodell, M. Satellites Measure Recent Rates of Groundwater Depletion in California's Central Valley. Geophys. Res. Lett. 2011, 38, doi:10.1029/2010gl046442.

10. Whittaker, B.N.; Reddish, D.J. Subsidence: Occurrence, Prediction, and Control; Elsevier: Amsterdam, The Netherlands, 1989.

11. Gambolati, G.; Teatini, P. Geomechanics of Subsurface Water Withdrawal and Injection. Water Resour. Res. 2015, 51, 3922-3955, doi:10.1002/2014wr016841.

12. Wade, C.M.; Cobourn, K.M.; Amacher, G.S.; Hester, E.T. Policy Targeting to Reduce Economic Damages From Land Subsidence. Water Resour. Res. 2018, 54, 4401-4416, doi:10.1029/2017wr022133.

13. Herrera, G.; Tomás, R.; Monells, D.; Centolanza, G.; Mallorquí, J.J.; Vicente, F.; Navarro, V.D.; Lopez-Sanchez, J.M.; Sanabria, M.; Cano, M. Analysis of Subsidence Using TerraSAR-X Data: Murcia Case Study. Eng. Geol. 2010, 116, 284-295, doi:10.1016/j.enggeo.2010.09.010.

14. Yang, Y.; Luo, Y.; Liu, M.; Wang, R.; Wang, H. Research of Features Related to Land Subsidence and Ground Fissure Disasters in the Beijing Plain. Proc. Int. Assoc. Hydrol. Sci. 2015, doi:10.5194/piahs-372-239-2015.

15. Béjar-Pizarro, M.; Ezquerro, P.; Herrera, G.; Tomás, R.; Guardiola-Albert, C.; Ruiz Hernández, J.M.; Fernández Merodo, J.A.; Marchamalo, M.; Martínez, R. Mapping Groundwater Level and Aquifer Storage Variations from InSAR Measurements in the Madrid Aquifer, Central Spain. J. Hydrol. 2017, 547, 678-689, doi:10.1016/j.jhydrol.2017.02.011.

16. Pratt, W.E.; Johnson, D.W. Local Subsidence of the Goose Creek Oil Field. J. Geol. 1926, 34, 577-590, doi:10.1086/623352.

17. Shah, T. Groundwater and Human Development: Challenges and Opportunities in Livelihoods and Environment. Water Sci. Technol. 2005, 51, 27-37, doi:10.2166/wst.2005.0217.

18. Galloway, D.L.; Burbey, T.J. Review: Regional Land Subsidence Accompanying Groundwater Extraction. Hydrogeol. J. 2011, 19, 1459-1486, doi:10.1007/s10040-011-0775-5.

19. Amitrano, D.; Di Martino, G.; lodice, A.; Mitidieri, F.; Papa, M.N.; Riccio, D.; Ruello, G. Sentinel-1 for Monitoring Reservoirs: A Performance Analysis. Remote Sens. 2014, 6, 10676-10693, doi:10.3390/rs61110676.

20. Bozzano, F.; Esposito, C.; Franchi, S.; Mazzanti, P.; Perissin, D.; Rocca, A.; Romano, E. Understanding the Subsidence Process of a Quaternary Plain by Combining Geological and Hydrogeological Modelling with Satellite InSAR Data: The Acque Albule Plain Case Study. Remote Sens. Environ. 2015, 168, 219-238, doi:10.1016/j.rse.2015.07.010.

21. Ezquerro, P.; Herrera, G.; Marchamalo, M.; Tomás, R.; Béjar-Pizarro, M.; Martínez, R. A Quasi-Elastic Aquifer Deformational Behavior: Madrid Aquifer Case Study. J. Hydrol. 2014, 519, 1192-1204, doi:10.1016/j.jhydrol.2014.08.040.

22. Ezquerro, P.; Guardiola-Albert, C.; Herrera, G.; Fernández-Merodo, J.A.; Béjar-Pizarro, M.; Bonì, R. Groundwater and Subsidence Modeling Combining Geological and Multi-Satellite SAR Data over the Alto Guadalentín Aquifer (SE Spain). Geofluids 2017, doi:10.1155/2017/1359325.

23. Bonì, R.; Cigna, F.; Bricker, S.; Meisina, C.; McCormack, H. Characterisation of Hydraulic Head Changes and Aquifer Properties in the London Basin Using Persistent Scatterer Interferometry Ground Motion Data. J. Hydrol. 2016, 540, 835-849, doi:10.1016/j.jhydrol.2016.06.068.

24. Bonì, R.; Meisina, C.; Cigna, F.; Herrera, G.; Notti, D.; Bricker, S.; McCormack, H.; Tomás, R.; Béjar-Pizarro, M.; Mulas, J.; et al. Exploitation of Satellite A-DInSAR Time Series for Detection, Characterization and Modelling of Land Subsidence. Geosciences 2017, 7, 25, doi:10.3390/geosciences7020025.

25. Crosetto, M.; Monserrat, O.; Cuevas-González, M.; Devanthéry, N.; Crippa, B. Persistent Scatterer Interferometry: A Review. ISPRS J. Photogramm. Remote Sens. 2016, 115, 78-89, doi:10.1016/j.isprsjprs.2015.10.011.

26. Ferretti, A.; Fumagalli, A.; Novali, F.; Prati, C.; Rocca, F.; Rucci, A. A New Algorithm for Processing Interferometric Data-Stacks: SqueeSAR. IEEE Trans. Geosci. Remote Sens. 2011, 49, 3460-3470, doi:10.1109/TGRS.2011.2124465.

27. Hooper, A.J. A Multi-Temporal InSAR Method Incorporating Both Persistent Scatterer and Small Baseline Approaches. Geophys. Res. Lett. 2008, 35, doi:10.1029/2008GL034654.

28. Cigna, F.; Tapete, D.; Garduño-Monroy, V.H.; Muñiz-Jauregui, J.A.; García-Hernández, O.H.; Jiménez-Haro, A. WideArea InSAR Survey of Surface Deformation in Urban Areas and Geothermal Fields in the Eastern Trans-Mexican Volcanic Belt, Mexico. Remote Sens. 2019, 11, 2341, doi:10.3390/rs11202341. 
29. Farolfi, G.; Del Soldato, M.; Bianchini, S.; Casagli, N. A Procedure to Use GNSS Data to Calibrate Satellite PSI Data for the Study of Subsidence:An Example from the North-Western Adriatic Coast (Italy). Eur. J. Remote. Sens. 2019, 1-10, doi:10.1080/22797254.2019.1663710.

30. Morishita, Y.; Lazecky, M.; Wright, T.J.; Weiss, J.R.; Elliott, J.R.; Hooper, A. LiCSBAS: An Open-Source Insar Time Series Analysis Package Integrated with the LiCSAR Automated Sentinel-1 InSAR Processor. Remote Sens. 2020, 12, 424, doi:10.3390/rs12030424.

31. European Space Agency. Sentinel-1-Missions-Sentinel. Available online: https://sentinel.esa.int/web/sentinel/missions/sentinel-1 (accessed on 21 March 2020).

32. Allison, M.; Yuill, B.; Törnqvist, T.; Amelung, F.; Dixon, T.; Erkens, G.; Stuurman, R.; Jones, C.; Milne, G.; Steckler, M.; et al. Global Risks and Research Priorities for Coastal Subsidence. Eos 2016, 97, doi:10.1029/2016eo055013.

33. Hu, B.; Chen, X.; Zhang, X. Using Multisensor SAR Datasets to Monitor Land Subsidence in Los Angeles from 2003 to 2017. J. Sens. 2019, doi:10.1155/2019/9389820.

34. Castellazzi, P.; Arroyo-Domínguez, N.; Martel, R.; Calderhead, A.I.; Normand, J.C.L.; Gárfias, J.; Rivera, A. Land Subsidence in Major Cities of Central Mexico: Interpreting InSAR-Derived Land Subsidence Mapping with Hydrogeological Data. Int. J. Appl. Earth Obs. Geoinf. 2016, 47, 102-111, doi:10.1016/j.jag.2015.12.002.

35. Jones, C.E.; An, K.; Blom, R.G.; Kent, J.D.; Ivins, E.R.; Bekaert, D.P. Anthropogenic and Geologic Influences on Subsidence in the Vicinity of New Orleans, Louisiana. J. Geophys. Res. Solid Earth 2016, doi:10.1002/2015JB012636.

36. Thoang, T.T.; Giao, P.H. Subsurface Characterization and Prediction of Land Subsidence for HCM City, Vietnam. Eng. Geol. 2015, 199, 107-124, doi:10.1016/j.enggeo.2015.10.009.

37. Pirouzi, A.; Eslami, A. Ground Subsidence in Plains around Tehran: Site Survey, Records Compilation and Analysis. Int. J. Geo-Eng. 2017, doi:10.1186/s40703-017-0069-4.

38. Aobpaet, A.; Cuenca, M.C.; Hooper, A.; Trisirisatayawong, I. InSAR Time-Series Analysis of Land Subsidence in Bangkok, Thailand. Int. J. Remote Sens. 2013, 34, 2969-2982, doi:10.1080/01431161.2012.756596.

39. Guo, L.; Gong, H.; Zhu, F.; Zhu, L.; Zhang, Z.; Zhou, C.; Gao, M.; Sun, Y. Analysis of the Spatiotemporal Variation in Land Subsidence on the Beijing Plain, China. Remote Sens. 2019, 11, 1170, doi:10.3390/rs11101170.

40. Jafari, F.; Javadi, S.; Golmohammadi, G.; Karimi, N.; Mohammadi, K. Numerical Simulation of Groundwater Flow and Aquifer-System Compaction Using Simulation and InSAR Technique: Saveh Basin, Iran. Environ. Earth Sci. 2016, 75, doi:10.1007/s12665-016-5654-x.

41. Rahmawati, N.; Vuillaume, J.F.; Purnama, I.L.S. Salt Intrusion in Coastal and Lowland Areas of Semarang City. J. Hydrol. 2013, 494, 146-159, doi:10.1016/j.jhydrol.2013.04.031.

42. Faunt, C.C.; Sneed, M.; Traum, J.; Brandt, J.T. Water Availability and Land Subsidence in the Central Valley, California, USA. Hydrogeol. J. 2016, 24, 675-684, doi:10.1007/s10040-015-1339-x.

43. Maps-UNESCO Land Subsidence International Initiative. Available online: https://www.landsubsidenceunesco.org/maps/ (accessed on 2 June 2020).

44. Center for International Earth Science Information Network - CIESIN - Columbia University. 2018. Gridded Population of the World, Version 4 (GPWv4): Population Density, Revision 11. Palisades, NY: NASA Socioeconomic Data and Applications Center (SEDAC). https://doi.org/10.7927/H49C6VHW (accessed on 2 June 2020).

45. Hole, J.K.; Bromley, C.J.; Stevens, N.F.; Wadge, G. Subsidence in the Geothermal Fields of the Taupo Volcanic Zone, New Zealand from 1996 to 2005 Measured by InSAR. J. Volcanol. Geotherm. Res. 2007, 166, 125-146, doi:10.1016/j.jvolgeores.2007.07.013.

46. Chaussard, E.; Wdowinski, S.; Cabral-Cano, E.; Amelung, F. Land Subsidence in Central Mexico Detected by ALOS InSAR Time-Series. Remote Sens. Environ. 2014, 140, 94-106, doi:10.1016/j.rse.2013.08.038.

47. Hu, R.L.; Yue, Z.Q.; Wang, L.C.; Wang, S.J. Review on Current Status and Challenging Issues of Land Subsidence in China. Eng. Geol. 2004, 76, 65-77, doi:10.1016/j.enggeo.2004.06.006.

48. Zhu, L.; Gong, H.; Li, X.; Wang, R.; Chen, B.; Dai, Z.; Teatini, P. Land Subsidence Due to Groundwater Withdrawal in the Northern Beijing Plain, China. Eng. Geol. 2015, 193, 243-255, doi:10.1016/j.enggeo.2015.04.020.

49. Qin, H.; Andrews, C.B.; Tian, F.; Cao, G.; Luo, Y.; Liu, J.; Zheng, C. Groundwater-pumping optimization for landsubsidence control in Beijing plain, China. Hydrogeol. J. 2018, 26, 1061-1081, doi:10.1007/s10040-017-1712-z.

50. Tomas, R.; Herrera, G.; Cooksley, G.; Mulas, J. Persistent Scatterer Interferometry Subsidence Data Exploitation Using Spatial Tools: The Vega Media of the Segura River Basin Case Study. J. Hydrol. 2011, 400, 411-428, doi:10.1016/j.jhydrol.2011.01.057.

51. Taylor, R.G.; Scanlon, B.; Döll, P.; Rodell, M.; Van Beek, R.; Wada, Y.; Longuevergne, L.; Leblanc, M.; Famiglietti, J.S.; Edmunds, M.; et al. Ground water and climate change. Nat. Clim. Chang. 2012, 3, 322-329, doi:10.1038/nclimate1744.

52. Wada, Y.; Van Beek, L.P.H.; Van Kempen, C.M.; Reckman, J.W.T.M.; Vasak, S.; Bierkens, M.F.P. Global Depletion of Groundwater Resources. Geophys. Res. Lett. 2010, 37, doi:10.1029/2010GL044571.

53. Wada, Y.; Bierkens, M.F.P. Sustainability of Global Water Use: Past Reconstruction and Future Projections. Environ. 
Res. Lett. 2014, 9, doi:10.1088/1748-9326/9/10/104003.

54. Konikow, L.F. Long-Term Groundwater Depletion in the United States. Ground Water 2014, 53, 2-9, doi:10.1111/gwat.12306.

55. Gleeson, T.; Alley, W.M.; Allen, D.M.; Sophocleous, M.A.; Zhou, Y.; Taniguchi, M.; Vandersteen, J. Towards Sustainable Groundwater Use: Setting Long-Term Goals, Backcasting, and Managing Adaptively. Ground Water 2012, 50, 19-26, doi:10.1111/j.1745-6584.2011.00825.x.

56. Landes, A.A.L.; Aquilina, L.; De Ridder, J.; Longuevergne, L.; Page, C.; Goderniaux, P. Investigating the respective impacts of groundwater exploitation and climate change on wetland extension over 150 years. J. Hydrol. 2014, 509, 367-378, doi:10.1016/j.jhydrol.2013.11.039.

57. Poland, J.F. Guidebook to Studies of Land Subsidence Due to Ground-Water Withdrawal; UNESCO: Paris, France, 1984.

58. Galloway, D.L.; Hoffmann, J. The Application of Satellite Differential SAR Interferometry-Derived Ground Displacements in Hydrogeology. Hydrogeol. J. 2007, 15, 133-154, doi:10.1007/s10040-006-0121-5.

59. Hoffmann, J.; Zebker, H.A.; Galloway, D.L.; Amelung, F. Seasonal Subsidence and Rebound in Las Vegas Valley, Nevada, Observed by Synthetic Aperture Radar Interferometry. Water Resour. Res. 2001, 37, 1551-1566, doi:10.1029/2000WR900404.

60. Schmidt, D.A.; Bürgmann, R. Time-Dependent Land Uplift and Subsidence in the Santa Clara Valley, California, from a Large Interferometric Synthetic Aperture Radar Data Set. J. Geophys. Res. Solid Earth 2003, 108, doi:10.1029/2002jb002267.

61. Galloway, D.L.; Hudnut, K.W.; Ingebritsen, S.E.; Phillips, S.P.; Peltzer, G.; Rogez, F.; Rosen, P.A. Detection of Aquifer System Compaction and Land Subsidence Using Interferometric Synthetic Aperture Radar, Antelope Valley, Mojave Desert, California. Water Resour. Res. 1998, 34, 2573-2585, doi:10.1029/98WR01285.

62. Canuti, P.; Casagli, N.; Farina, P.; Marks, F.; Feretti, A.; Menduni, G. Land Subsidence in the Arno River Basin Studied through SAR Interferometry. In Land Subsidence, Proceedings of the Seventh International Symposium on Land Subsidence, Shanghai, China, 23-28 October, Shanghai Institute of Geological Survey: Shanghai, China, 2005; Volume 1, 407-416.

\section{Keywords}

land subsidence; groundwater pumping; aquifer compaction; modelling; InSAR

(C) 2020 by the author(s). Distribute under a Creative Commans CC BY license 